\title{
Soil and Forest: The Key Factors for Human Survival
}

\author{
Shyi-Min $\mathrm{Lu}^{1}$ \\ ${ }^{1}$ Energy and Environmental Laboratories, Industrial Technology Research Institute, Chutung, Hsinchu, Taiwan \\ Correspondence: Shyi-Min Lu, 11F-1, No. 58, Sec. 5, Nanking East Road, Taipei 10597, Taiwan. Tel: \\ 886-910-354-790. E-mail: shyimin@gmail.com
}

Received: March 5, 2017

doi:10.5539/jsd.v10n3p105
Accepted: March 28, 2017 Online Published: May 31, 2017

URL: https://doi.org/10.5539/jsd.v10n3p105

\begin{abstract}
From the past to the future, the development of human civilization has been closely related to the Earth's soil. However, we are now on the planet with the productive forces of soil resources that are gradually exhausting. In many agricultural areas, crop yields have been devastated by heavy soil erosion. Nitrogen fertilizers and fossil fuels in geological reservoirs tend to be scarce, resulting in both the increase of agricultural production costs and the increase of geopolitical conflict. Global warming, on the other hand, accelerates microbial greenhouse gases (GHG) released in soils and has a key role in recent climate change. In this paper, we show the challenges faced by human beings in the 21 st century because of the direct and indirect responses of the soil expansion made by human past and future activities. We also stress that soil and forest are the future survival and development key factors for human beings. This global trend of development should be the recommendations for Taiwanese future development policy of land and forest.
\end{abstract}

Keywords: soil, forest, climate, food, environment

\section{Introduction}

The soil is a living skin on a planet. Globally, some atmospheric gases circulate through the soil, which is partially filtered and stored in the hydrological cycle (Koch et al., 2013; Marengo et al., 2012). In addition, the soil is a large-scale dynamic storage of carbon, which is also the base of most of our food production. However, there will be significant changes in these interrelated functions - in particular climate and food production - that are likely to trigger a series of major shocks to human society in this century. Basically, the way humans directly and indirectly manage the earth's soil will be intertwined with our future ability to continue the fate of a living spicy on Earth (Amundson et al., 2015).

The soil is usually identified as an altered rock or deposit approximately 1 meter thick beneath the surface and exposed to the atmosphere, thereby obtaining many constituent characteristics (Figure 1). The chemical reaction of soil formation creates special micro-negatively charged clay minerals that give the soil the nutrients necessary for plant growth (Sposito et al., 1999). The charge characteristics of the soil, coupled with its small particle size and high specific surface area, temporary storage of rainwater and snow melt for plant to absorb, sufficient water retention time, trigger a variety of chemical reactions, remove or reduce toxic pollutants. Water stored in the soil - known as green water - accounts for $90 \%$ of the global agricultural production and $65 \%$ of the global fresh water. Finally, the three interweaves of the Earth's life chain - plants, animals, and microbes - produce redox reactions that can control the cycling of many elements in a large container of soil (Bardgett et al., 2014), especially with organic carbon storage, far beyond the total carbon contents contained in the atmosphere and the bio-chain (Jobbágy \& Jackson, 2000). The microbial communities that mediate these redox reactions are recognized as representative of the Earth's biodiversity (Wall et al., 2010). However, the exploration items of the nature, function, and economic benefits of these soil biological chains are only just beginning.

Because of the global changes in climate, geology and biota, soils have great spatial diversity. In the United States alone, more than 20,000 soil types (or soils) are identified and their numbers increase with the size of the surveyed land area (Amundson et al., 2003). If this proportion is extrapolated to the global ice-free land (Guo \& Amundson, 2003), Earth has more than 300,000 of the soil system exist. 


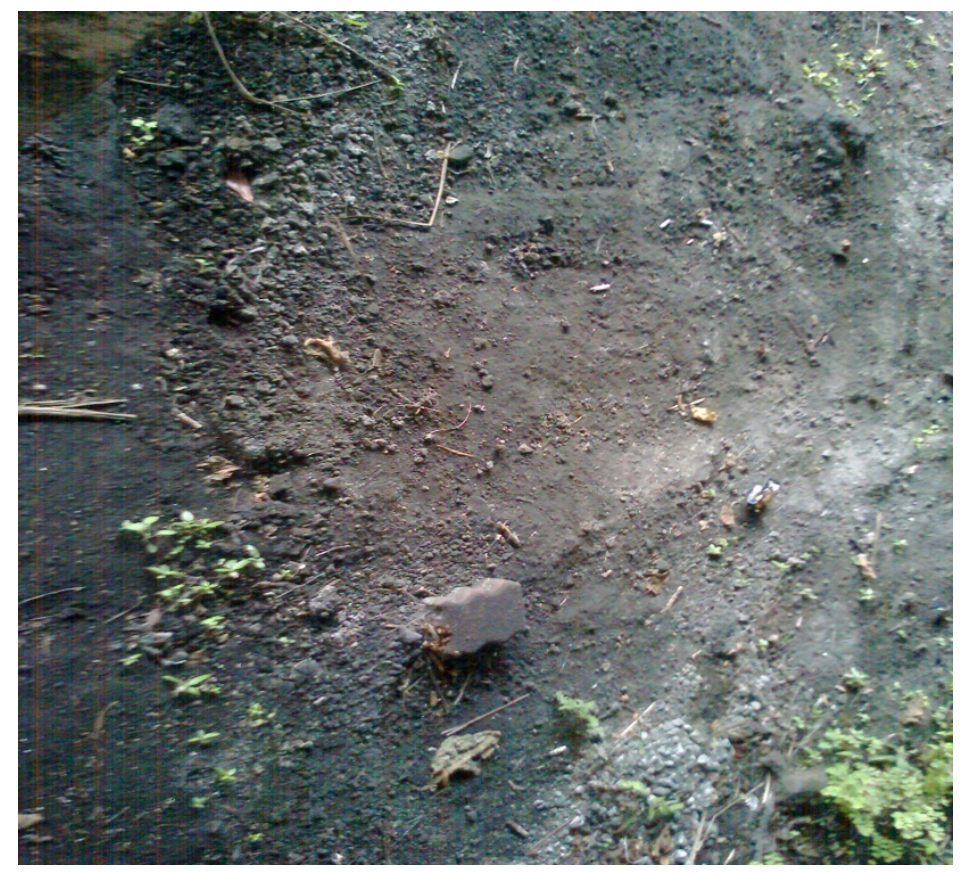

Figure 1. The soil is usually identified as an alteration rock or deposit about 1 meter thick beneath the earth surface and is exposed to the atmosphere, thereby obtaining many constituent characteristics

\section{The Human Footprint on the Soil}

When it began to expand the range of activities on Earth, humans have been changing the ecosystem encountered (Lieth, 1973). However, the moment of maximum change in the soil itself lies in the human invention of agriculture (Diamond, 2002). Most agriculture involves the destruction of natural flora, the simplification of biological diversity, and the destruction of soil physical properties. Since the Industrial Revolution, the growing population has relied on the development of more and more land in response to the relative increase in the production of food. Today, 12 percent of the ice-free land surface is used for tillage, 38 percent for mixed cropping and grazing, which is roughly the same area as the land area of last glacial maximum snow cover, erosion or other disturbances. In addition to the similarity in area, the rate and magnitude of agricultural impact on soil treatment far exceed those of ice sheets.

As a result of many feedback mechanisms, undisturbed soils can retain permanent features that follow the passage of time, such as thickness, carbon content, and nutrients, which is equivalent to a sustainable eco-system. However, due to the human civilization, the vast majority of wild original soil is highly modified into the form of arable land. Cultivated soils rarely retain their original qualities, greatly affecting their productivity, and impacting the surrounding geochemical cycles. Improving the management and conservation of these soils and preserving their remaining primitive qualities will be one of the most important challenges of this century (Tennesen, 2014). The study of the effects of agriculture and urbanization on soil systems shows that 50 percent of the original soil has been cultivated in the agricultural heartland of the United States. The diversity of soils, such as the diversity of microorganisms (Ehrlich and Wilson, 1991), and the availability of goods and services are invaluable to humans, especially how to provide sustainable agricultural productivity from the soil has become one of the most important issues currently.

The soil with agricultural productivity is one of the most valuable commodities on Earth. For example, the global output value of agricultural products is about 3.816 trillion US dollars in 2012. However, agricultural land is gradually replaced by urban and suburban residential land. We should know that, in human time scale, once the natural soil changed into residential land, it will be an irreversible role in the conversion. But the human habitation land on earth has been continuously increasing. A recent analysis shows that between 1970 and 2000, roughly half the size of the Danish land was urbanized and that 1.5 million square kilometers (about the size of the Mongolian area) would be urbanized in the next 20 years (Figure 2). Rapid conversion of farmland into urban areas has addressed the fact that human productive soils are gradually disappearing, but the demand for food production is increasing. 


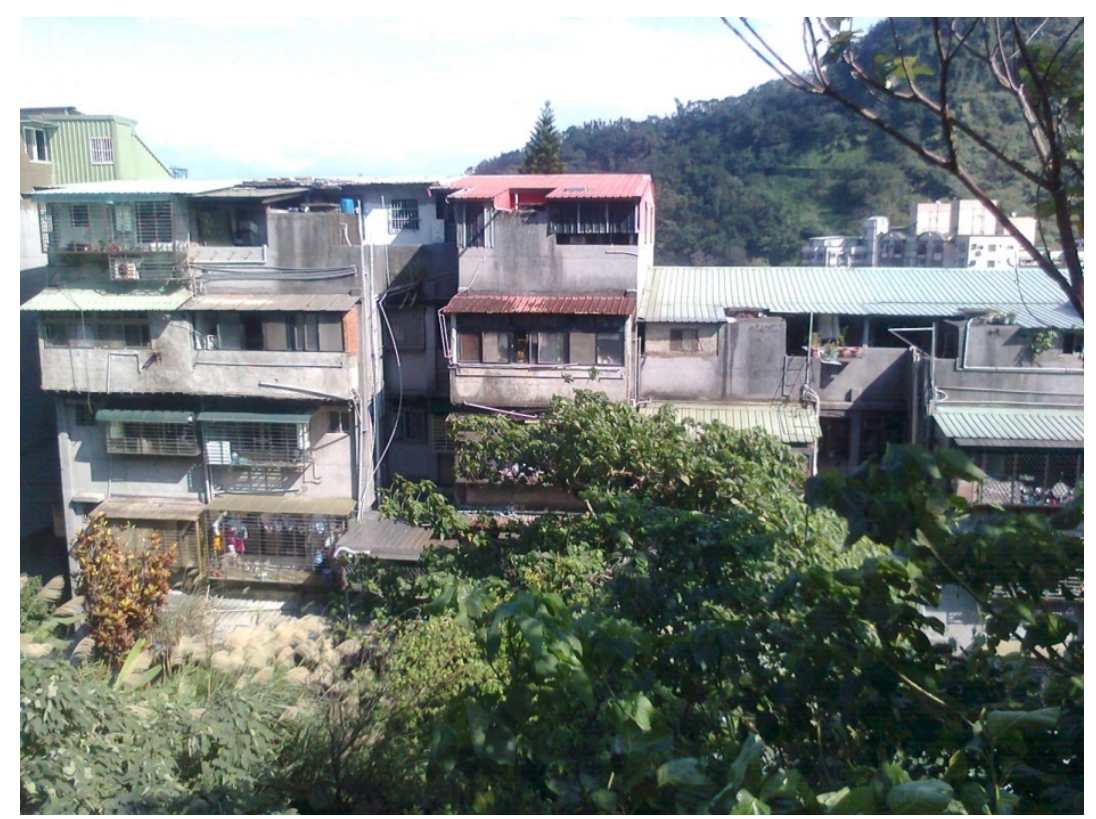

Figure 2. In the next 20 years, there will be 1.5 million square kilometers of land (about the size of Mongolia) urbanized

\section{Soil and Climate Change}

Humans have always taken the relatively stable climate as the main stage of civilization, such as agriculture and industry. However, the soil carbon cycle changes made by human activities have a great impact on the greenhouse gas concentrations in the atmosphere and on the global climate as well.

Essentially, the organic carbon stored in the soil is balanced by the cycling of carbon dioxide uptake and release between plants and microorganisms. In the undisturbed conditions, soils have maintained stable carbon stocks for millennia over thousands of years, and recent estimates indicate that 2.3 trillion tonnes of organic carbon is accumulated in the soils 3 meters deep beneath the surface. Soil cultivation has been a major source of anthropogenic greenhouse gas emissions since the 19th century (Sundquist, 1993). Organic carbon is accumulated in the soil for thousands of years through the effective regulation by microbes (Guo \& Gifford, 2002). Farming has severely damaged the carbon balance in the soil, because it changes the physical and biological structure of the soil (Stockmann et al., 2013). During the first decades of soil cultivation, about $50 \%$ of the carbon is oxidized into carbon dioxide; finally, a stable carbon cycle is formed. Based on the area of global agriculturally arable land, 50 to 70 billion tonnes of carbon have emitted into the atmosphere in the history of mankind (Amundson, 2001), far exceeding the amount of carbon dioxide emitted by combusting fossil fuels in the 20th century (Gedney et al., 2006). However, the increase in greenhouse gas concentrations in agriculture can be traced back to the Holocene (Ruddiman, 2013). The early atmospheric $\mathrm{CO}_{2}$ and $\mathrm{CH}_{4}$ peaks coincided with the agricultural expansions in Mesopotamia and China at that time. Most of the historical carbon loss lies in the soils use of forests and grasslands in northern latitudes (Ruddiman, 2007). Today, however, the trajectory of land changes has shifted to the equatorial latitudes, accounting for $10 \%$ of global anthropogenic carbon dioxide emissions, mainly resulted from the biomass burning and soil farming in the tropics.

If through effective soil management in the next five years, the global agricultural arable land has the potential to store carbon losses resulted from fossil fuels burning in a period of ten years. Increasing soil organic carbon content with good cropland management is a valuable implementation option in terms of both ecological and agronomic perspectives (Jackson \& Schlesinger, 2004). At present, many scholars study the feasibility of such carbon sequestration with different soil management methods. However, these efforts in mitigating the carbon emissions from fossil fuels may also have been limited. First, the serious concerns of implementing a carbon sequestration strategy with soil management include: (1) In a highly decentralized and economically driven agricultural sector, the strict management practices are important, once the land ownership changes or the factors driving the agricultural implementation changes (Smith, 2005); (2) The effect of soil carbon sequestration is time-dependent; for example, if all potential soil carbon sequestration strategies are established, the initially estimated carbon storage capacity will be increased about 1.3 billion tonnes annually (Table 1) (Smith et al., 
2007), but because of this new carbon balance in soil, about a few years later, the carbon storage rate will be nonlinearly slow (Smith et al., 2008); (3) The greatest potential for achieving this goal is equally important, which includes the difficulties involving multinational governments and millions of land managers; and, (4) the effect of such soil management on carbon sequestration is limited, compared with the impact of global climate on soil carbon storage.

Table 1. The carbon fluxes obtained using various soil management methods in the 21 st century are predicted from known literature

\begin{tabular}{|c|c|c|c|}
\hline Soil management & $\begin{array}{l}\text { Maximum flux (100 million } \\
\text { tons of carbon per year) }\end{array}$ & $\begin{array}{l}\text { Cumulative flux (100 } \\
\text { million tons) }\end{array}$ & Reference \\
\hline \multicolumn{4}{|c|}{ Carbon pool } \\
\hline $\begin{array}{l}\text { Increase net primary } \\
\text { productivity }\end{array}$ & & $1600 \sim 12,300$ & (Todd-Brown 2014) \\
\hline Loss & 4 & 400 & (Doetterl et al., 2012) \\
\hline \multicolumn{4}{|c|}{ Management } \\
\hline $\begin{array}{l}\text { Cultivated land } \\
\text { management }\end{array}$ & 3.6 & & $\begin{array}{l}\text { (Smith et al.,. 2007, } \\
\text { Smith et al., 2008) }\end{array}$ \\
\hline Pasture management & 3.7 & & $\begin{array}{c}\text { (Smith et al., 2007, Smith } \\
\text { et al., 2008) }\end{array}$ \\
\hline Restore degraded land & 1.8 & & $\begin{array}{c}\text { (Smith et al., 2007, Smith } \\
\text { et al., 2008) }\end{array}$ \\
\hline Reduction of organic soil & 3.6 & & $\begin{array}{c}\text { (Smith et al., 2007, Smith } \\
\text { et al., 2008) }\end{array}$ \\
\hline $\begin{array}{l}\text { Management related } \\
\text { totals }\end{array}$ & 12.6 & $164^{*}$ & \\
\hline \multicolumn{4}{|c|}{ Carbon source } \\
\hline Land reclamation $^{+}$ & & 2500 & \\
\hline $\begin{array}{l}\text { Soil warming in frigid } \\
\text { area }\end{array}$ & & $50 \sim 270$ & (Burke et al., 2012) \\
\hline Global totals & & $104 \sim 629$ & $\begin{array}{c}\text { (Todd-Brown et al., } \\
\text { 2013) }\end{array}$ \\
\hline Net balance & & $-188 \sim+137$ & \\
\hline
\end{tabular}

* Based on the largest newly arable land before 2050 (i.e., 10 billion hectares), assuming $25 \%$ average loss rate of carbon content in every $10 \mathrm{kgm}^{-2}$ of soil

+ Assuming an exponential decrease and reaching the final landscape saturation point after 50 years

According to the literature data, soil carbon storage will decrease with increasing temperature and decreasing soil moisture. Therefore, the soil carbon storage pattern varies in different climatic regions around the world (Post et al., 1982). The other basically influencing factors are bedrock, topography and soil age. The soil carbon cycle reaches equilibrium between plant and microbial uptake and release (Figure 3). The effects of anthropogenic climate change on these processes are considered to be the largest and most difficult to control (especially in the case of carbon inputs), and the most complex (due to temperature-humidity interaction). In fact, as long as there is no nutrient absence and water scarcity, anthropogenic increase in atmospheric carbon dioxide can increase the net primary productivity (NPP) (Todd-Brown et al., 2014). As the input of soil carbon increases, the negative feedbacks to atmospheric $\mathrm{CO}_{2}$ will eventually occur (Figure 3). On the other hand, increasing the air temperature will warm the soil, thaw the frozen soil layer, and stimulate the bioaccumulation of the soil carbon pool, which appears to be a large positive feedback process (Figure 3). According to the current Earth System Modeling (Amundson et al., 2015), soil carbon storage is increased by increasing NPP (relative to the BCE date of 1850 ) between 160 and 1230 billion tonnes by 2100 , while the increase in soil carbon loss is 104-629 billion 
tonnes through microbial decomposition. Overall, the model shows that there will be 72 billion tonnes of carbon losses and 253 billion tonnes of carbon gains by 2100 via soil carbon change (Litchman et al., 2015). However, such simulations include the uncertainty about the expected benefits of enhanced photosynthesis by $\mathrm{CO}_{2}$ and the loss of soil warming, as well as the assumption that carbon dioxide concentrations are increasing in response to long-term ecosystems (Cao et al., 2010). One of the important uncertainties is the warming of soils in the northern latitude, which could result in a net soil carbon loss between 50 and 150 billion tonnes. Finally, the Earth's carbon generation model is difficult to cope with the current soil carbon storage model. In addition, the global soil carbon cycle experience uncertainty is up to 770 billion tonnes, which is a big challenge to adjust the model (Todd-Brown et al., 2013). This uncertainty value is also approximately equal to that of the current atmospheric carbon cycle.

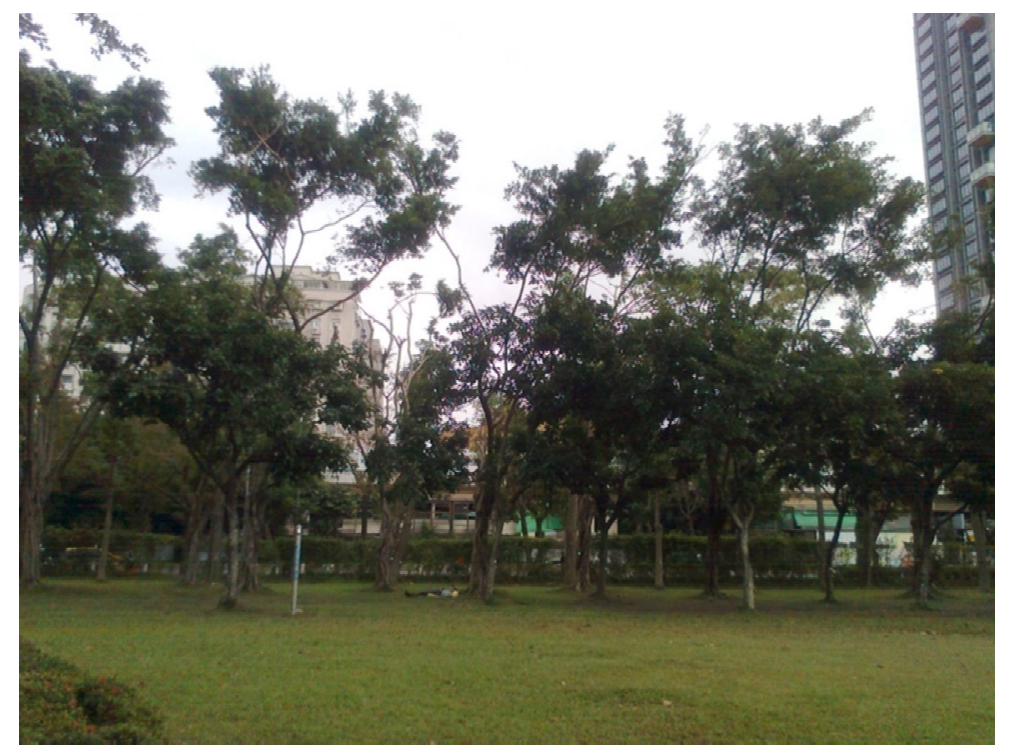

Figure 3. The organic carbon stored in the soil is balanced by the cycling of carbon dioxide uptake and release between plants and microorganisms

The impact of soil erosion on the global carbon cycle is still controversial. When the agricultural soil is lost by water or wind erosion, most of the carbon-rich material on the surface is preferentially removed, thus accelerating the decline of soil carbon stocks. The rate of soil carbon replacement by crops and plants is sufficient to stabilize the carbon loss state in some cases, thereby maintaining soil carbon levels, i.e., the soil layer can create a continuous carbon reservoir (Figure 4). This carbon storage stock represents a net reduction in carbon dioxide in the atmosphere, but only if the lost carbon is no longer re-oxidized, since several depositional environments favor partial preservation of buried carbon, such as lakes, reservoirs, basins, floodplains, and the like. The first proposed net effect of accelerating agricultural carbon losses is 0.6-1.5 billion tonnes per year, which is close to the total global terrestrial carbon storage (Stallard, 1998). However, if the loss of carbon is greatly oxidized, it may result in no net storage or even no net source (Lal et al., 2008). The latest estimates suggest that the rate of carbon loss from agricultural soils is between $0.4 \pm 0.2$ billion tonnes of carbon per year. If we benefit from accidental carbon sinks caused by soil erosion, any other relative benefit must be balanced, i.e., reduced nutrient availability and reduced environmental quality need to be compensated from fossil fuel energy (Quinton et al., 2010).

Global soil carbon cycling has been greatly disturbed by human activities, whether direct agricultural practices or indirect anthropogenic climate changes. All the predicted soil carbon's gain and loss in this century are highly uncertain due to economic, demographic, and political influences (which will have a significant impact on carbon storage efforts), with additional uncertainties regarding soil warming (because the soil carbon cycle has a very complex structure). Changes in global atmospheric climate, resulted by human activities, are likely to drive soil carbon gain and loss at the same amount as the emissions of burning fossil fuels for decades. The unknown balance between the current high fluxes, and most importantly the positive or negative values, represents a considerable uncertainty in climate security (Table 1). 


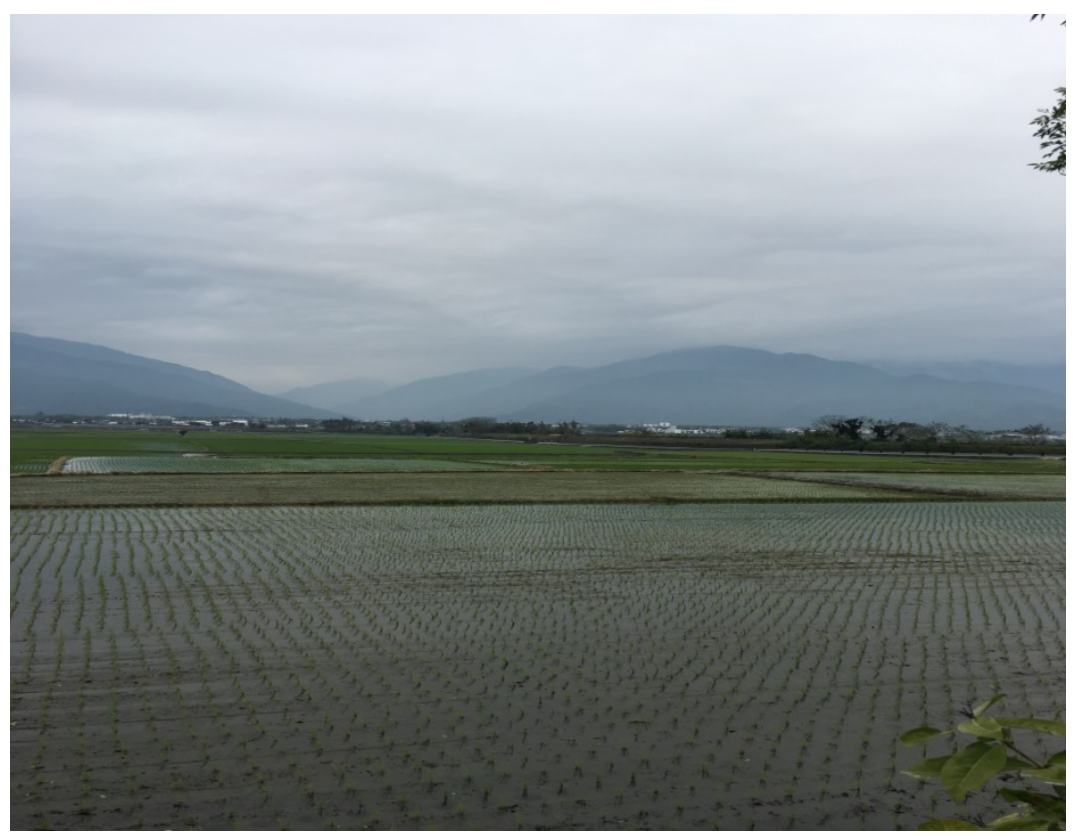

Figure 4. The rate of soil carbon replacement by crops and plants is sufficient to stabilize the carbon loss state in some cases, thereby maintaining soil carbon levels, i.e., the soil layer can create a continuous carbon reservoir

\section{Soil and Food Security}

For the western industrialized countries, the end of the 20th century and the beginning of the 21 st century is an unprecedented era for the low price of food. However, there are many factors that could reverse this trend, such as increased global demand, climate change, and competition for soils for non-agricultural use, especially the influences of biofuels or urbanization (FAO, 2011). Abundant energy has always been a key force behind population expansion and adequate food production. It is predicted that the world's population will reach 11 billion by 2100. As a result of low-cost energy, people use advanced agricultural machinery to replace human labor, leading to population migration to cities. Basically, energy can be used to produce the soil nutrients needed for agriculture, and the first and most important green revolution is made possible by the energy-intensive Haber-Bosch procedure, which converts nitrogen in the air into the crop's absorbable ammonia fertilizer (Smil, 2011). Due to this revolution, we can feed the globally gradually increased population. Prior to the industrial nitrogen fixation, the increase in food production in any country was mainly due to the expansion of the area of grain produced. After the introduction of nitrogen fertilizer, the yield per hectare of the main crops began to rise. Finally, energy is a necessary source of power for mining and transporting plant-needed nutrients such as phosphorus and potassium that can only be obtained from limited geological reservoirs.

Soil erosion in agriculture is arguably one of the most devastating human activities or behaviors for sustainable soil development. In the foreseeable future, there is almost no chance or incentive to expand the scale of agriculture, so our existing soil management of arable land is essential to the continued prosperity of mankind. However, although the importance of soil and water conservation has been stressed, the implementation of measures to reduce soil erosion has not ever caught up with the deepening of the problem. The most common phenomenon of soil erosion is caused by water. Before the native plant's growth is replaced by farming and cultivation of the mankind, the geological mechanism of the vast majority of mountain soil and water losses is slow; basically, it is mainly a biologically driven creep (Kirkby, 1967). However, as a result of human reclamation and abusive construction, a large number of plant covers are removed. The natural loss mechanism of the soil is changed, allowing the raindrops to displace the soil particles and then to remove them by the slope flow, which is a more rapid soil loss process. In the absence of agriculture, soil loss is only about 21 meters per million years (Wilkinson \& McElroy, 2007). Today, the rate of soil erosion in the United States can be more than 2,000 meters per million years, while in the Chinese Loess Plateau, in part of which the soil loss rate is as high as 10,000 meters per million years (Sun et al., 2014). Basically, these lost sediments will eventually be replaced by underlying sediments or rocks, biological mechanisms, and newly converted soils with added organic matter and nutrients. However, little has been known about the pace of this alternative process over the last decade. Overall, 
the rate of soil erosion is currently around 400 meters per million years (Montgomery, 2007). In many analyzes, the rate of soil production in the natural environment is between 50 and 200 meters per million years, and these data clearly indicate that soil erosion in many agricultural areas has so far not been sustainable. Not only does soil erosion in agricultural areas lose the nutrients necessary for grain growth, but unfavorable sedimentation also affects the local aquatic ecosystems, water bodies, and aquatic ecosystems (Figure 5) (Janisch \& Harmon, 2002). Finally, in the face of accelerated soil erosion, maintaining or even increasing agricultural production will increase the use of energy. Although plant microbial symbiosis can fix nitrogen in the atmosphere into bioavailable forms or by means of human substitution like the Haber-Bosch process, but there is no biological process or atmospheric resource to produce earth-derived or rock-derived nutrients (such as phosphorus, potassium, and calcium). This issue is sufficient for the current agricultural policy-makers alerted.

Although soil can be produced, replaced or release nutrients naturally, the pace of these natural processes is still slow relatively to the rate at which people use the land (Figure 6). When crops are transported from production sites to other sites, the nutrients provided by the soil for the need of plant growth will be reduced, leading to a fall in production levels potentially (Jones et al., 2013; Levick \& Asner, 2013), further deepening reliance on the exploitation of geological resources and the distribution of large amounts of nutrients, finally resulting in national economic and geo-political conflicts (Cordell et al., 2009). The recent increase in the demand for phosphorus has led to a surge in the cost of phosphate rock, from $\$ 80$ per tonne in 1961 to $\$ 450$ per tonne in 2008. Prices have been fluctuating since then, now around $\$ 700$ per tonne. In addition to the cost increases, mining is also a difficult problem. According to estimated data, Morocco has the world's largest phosphorus geological reserves, but most of them are located in disputed areas. On the other hand, the United States contains only about $2 \%$ of the world's phosphate rock resources. According to current mining rate, the most productive phosphate sources in the United States will be depleted in 20 years, forcing imports of phosphorus increasingly dependent, thus to maintain the demands from agriculture and industry sectors.

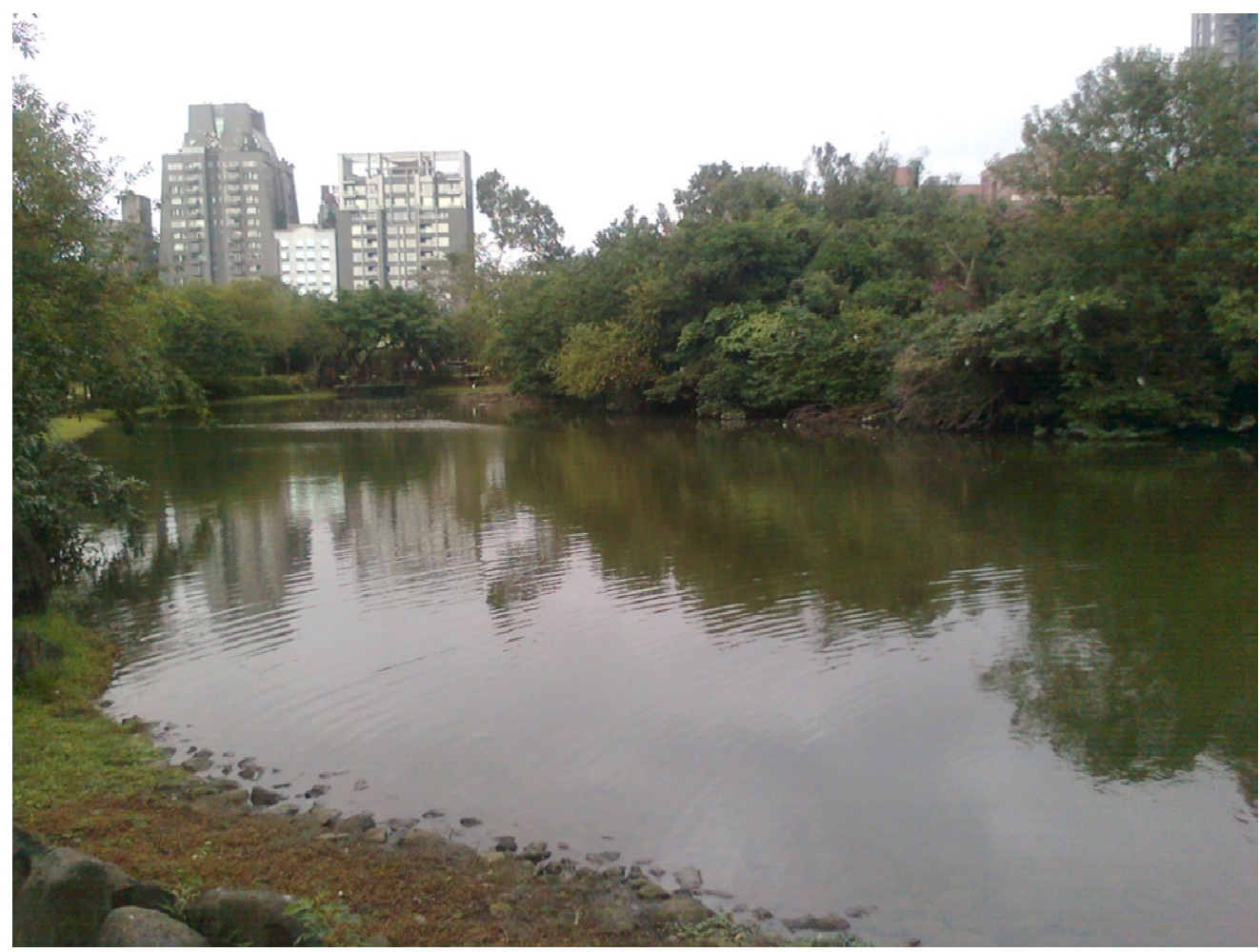

Figure 5. Not only does soil erosion in agricultural areas lose the nutrients necessary for grain growth, but also detrimental sedimentation can affect local water systems, water bodies, and aquatic ecosystems 


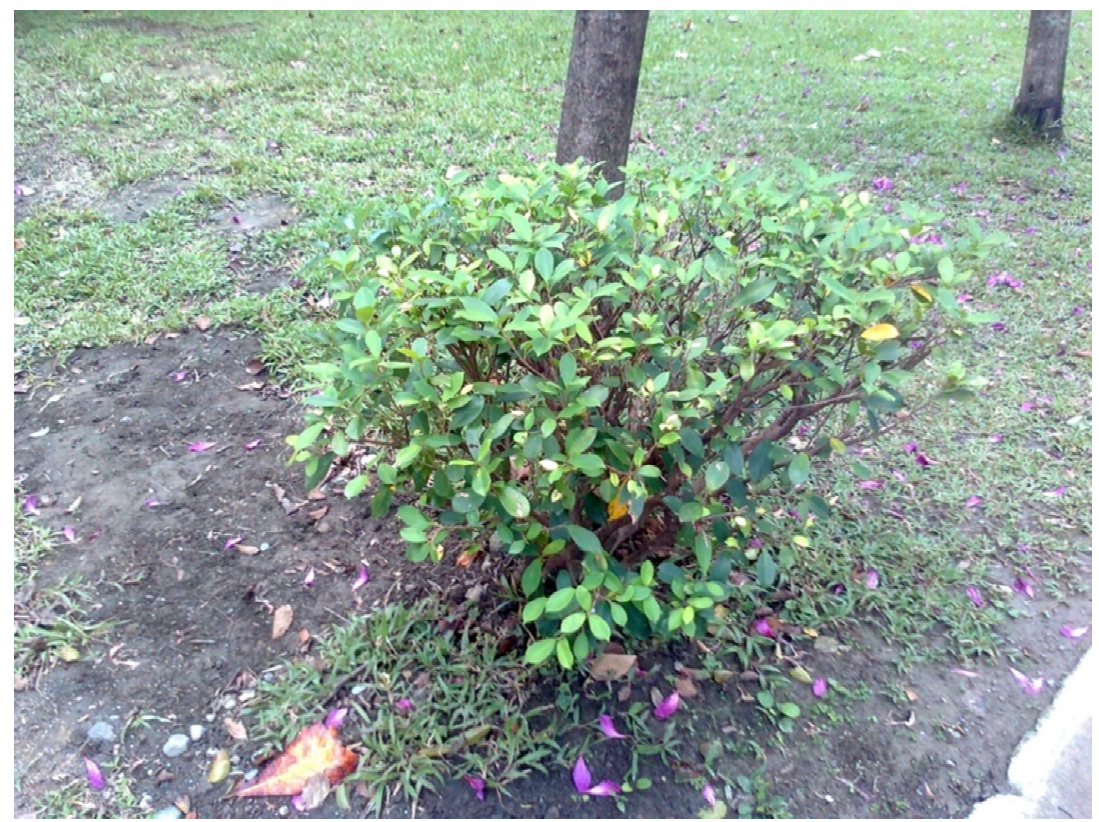

Figure 6. Although the soil naturally produces, replaces, or releases nutrients, the pace of these natural processes is slow relatively to the rate at which people use the land

The major phosphorus-dependent countries lack the relative geological resources. In order to maintain their current use indefinitely, besides the shift from production to import, the only means to maintain stocks is the establishment of consistency and integrated recycling systems for phosphorus and other nutrients. In human society, the soil nutrient loss and animal waste are regarded as a major problem of environmental and economic damage. Now, from the basic consensus in society, the waste recycling and resource control are very helpful for the reduction of imports and other resource needs (Elser \& Bennett, 2011). In addition to phosphorus, other soil nutrients appear to have entered a restricted or high demand era. Potash prices, for example, are expected to rise from about $\$ 875$ per tonne in 2009 to $\$ 1,500$ per tonne in 2020 .

\section{Challenges of the 21st Century}

The results of human reclamation of the earth's soil resources cause a number of soil cycles perturbation, so they are no longer in equilibrium. The imbalance changes the nature of the soil and indirectly or directly affects the survival of future generations, due to the Earth's climate change. Basically, the major principle of our soil management is to restore the disrupted soil resource system back to the original regenerative function. The strategy to restore the balance of soil should include following three soil elements: (1) organic carbon; (2) soil itself; and (3) nutrient. The ultimate goal of soil sustainability is to manage the global soil resources and to promote the implementation of relevant programs and research projects, such as the fixed nutrient quantity and the measurement of above-mentioned three elements of soil balance.

These goals are challenging and difficult to achieve. They need solutions to invest considerable human and material resources, because the existing problem is too large. First, to achieve an effective solution for soil sustainability, innovative mechanisms or institutions including highly cross-cutting research are needed, as are the models required to combat global climate change. Second, the ultimate requirement for any innovation is the establishment of a dialogue and communication channel with policymakers and public institutions, as the ultimate "decision-making" will involve large-scale social change. These interlocking efforts will depend on the acquisition and delivery of innovative knowledge, as well as the continuous expansion, pursuit, and input of different conceptual approaches to solve the problem. Our current mission is to make the future of the Earth's soil resources sustainable under our control in lifetime or within ability. In this critical twenty-first century, we will witness the struggle course for mankind survival.

\section{The Implication for Land Policy in Taiwan}

The soil classification results in Table 2 show that the most parts of Taiwan's farmland and sloping land are in the lack of fertility. In other words, soil nutrients and organic matter content are significantly inadequate, implying that soil fertility management is very important in Taiwan. In addition, according to the results of four standard 
classification categories, such as soil depth, soil texture, drainage class and soil reaction, the general characteristics of farmland and sloping land in Taiwan are belong to deep, non-acidic or calcareous, (medium) well-drained or slightly poor-drained loam soils. According to these four classification criteria, there are 69 soil types in Taiwan, and this simplified soil classification will be beneficial to soil management.

Table 2. The number and percentage of soil series in Taiwanese agricultural land and slope land under four classification criteria

\begin{tabular}{lcc}
\hline \multicolumn{1}{c}{ Classification criteria } & Number of soil categorization & Percentage (\%) \\
\hline Very shallow & Soil depth & 2.7 \\
Shallow & 25 & 6.5 \\
Medium depth & 60 & 12.5 \\
Deep & 115 & 17.7 \\
Very deep & 163 & 60.6 \\
\hline & 558 & \\
\hline Sand & Soil composition & 4.8 \\
Loam & 44 & 90.9 \\
Clay & 837 & 4.3 \\
\hline & 40 & 45.8 \\
\hline Excessive drainage & 13 & 40.6 \\
Good drainage + Medium good drainage & 422 & 12.2 \\
Slightly poor drainage & 374 & \\
Poor drainage + very poor drainage & 112 & 6.9 \\
\hline & Soil drainage & 47.0 \\
\hline Acidic & Soil reaction & 46.1 \\
Non-acidic & 64 & \\
Calcareous & 433 & \\
\hline
\end{tabular}

According to the Agricultural Statistics Annual Report data compiled by Agricultural Council of the Executive Yuan, Taiwan's arable land in the 1950s was about 870 thousand hectares, accounting for a quarter of Taiwanese total area; after the 1980s, the area of cultivated land decreased year by year from 910 thousand hectares in 1980 gradually fell to 810 thousand hectares in 2010. In Taiwan, the agricultural arable land is small or fragmented, unable to expand the scale of operation, leading to increased agricultural production costs.

Taiwan's early economic development, with agriculture as the main industrial structure, is closely related to agricultural land policy, but in the later years, the industrial structure is shifted to industry and commerce, so the agricultural land policy is changed accordingly. The results show that Taiwanese agricultural land policy is affected by different important factors at different critical moments: political considerations, economic development, ecological protection and rural community participation (Edmonds et al., 2000). As far as the Rural Rehabilitation Ordinance is concerned, when regarding the relative importance of the four key factors (i.e., the level of explanatory power), rural community participation is the highest, while the political factor is the lowest.

In the early years, Taiwanese government, to stabilize the overall social and economic development, often intervenes with the political power, in order to maintain the national development and social stability. Since of the democratization, the agricultural policy is still subject to political factors and the farmer autonomy is still relatively weak.

As early as 1992, when the United Nations called on all countries in the pursuit of economic development, the sustainable development of environmental ecology was paid attention and put forward in the Agenda 21. For 
example, the Government formulated the "Taiwanese Sustainable Development with Vision and Strategic Objectives for Agenda 21", which is aimed at the sustainable development of agriculture, and four goals are put forward: (1) Protection of good agricultural land, implementation of agricultural land development policy, management of slope land resource, and avoidance of the destruction of agricultural ecology; (2) Protection of fare agricultural production areas, avoiding the sporadic changes to affect the overall agricultural development; (3) Adjust the sloping land agricultural management policy, and maintain the sustainable use of sloping land resources; (4) The establishment of spatial database of agricultural land resources, planning of agricultural management space, taking into account the agricultural development and agricultural land use.

In May 2009, President Ma Ying-Jeou pushed the so-called "Small Landlord Big Farmer-Tenant" program in a main objective to promote farmland circulation and active farmland use. The government subsidized the farmers who had been unable to cultivate or the farmers who had no intention of re-cultivating their farmland, who rent their farmland ownership to the large farmers willing to expand their farm operations.

\section{How Do We Measure Forest Conditions and Assess Forest Health?}

Humans rely on healthy forests to provide energy, building materials, food, and many ecological and environmental protection functions, such as carbon storage, biodiversity, and climate regulation. Defining forest health involves both forest utility and ecosystems (Millar \& Stephenson, 2015). Although native forests can adapt to a certain degree of disturbance, almost all forests today face new forms of stress, including climate change, air pollution, and pest infestation. How to quantify these increasing pressures on forest growth is a major scientific challenge. It is particularly important to confirm that the Earth is acceptable to such a rapid rate of forest reduction, since the ability of the restoration forest to provide these functions may take decades to centuries.

Forests evolve in nature by a series of natural disasters, such as droughts, "wind-blown trees" (i.e., trees being uprooted by strong winds, or being overturned by wind), pest outbreaks, and fires. On the other hand, forests have to cope with increasing human-related pressures, directly: reclamation and deforestation; indirect: climate change, air pollution, species invasion and so on. These exacerbated disturbances happen too fast, beyond current range and rate of forest evolution; namely, the evolution of adaptation speed cannot keep up with the changes in the environment.

A common standard across all spatial scales shows (Asner et al., 2004), (1) practicality: sustainable supply of forest products and functions; and (2) ecosystems: the strength and resilience against stress and disturbance. Because it is beyond the human perception of space and time scale, some indicators cannot be directly measured or occurred. Existing forest health assessments ranged from absolute utility to relevant local manpower need the ecological definition or position of forest sustainability in a given landscape (Gauthier et al., 2015).

Basically, methods of monitoring global forest health require detection and observation of climate and biologically driven changes in forest conditions (Wingfield et al., 2015; Mildrexler et al., 2007). In addition, the trajectories of forest functions in recoverable declines can be identified on the bases of experiments and long-term observations. The implementation of this approach requires a technology scale that spans current remote sensing and mapping data.

When the concept of health is applied to the forest, the number of plants will be involved in this common problem. On a single tree scale, health can be defined as the state without disease. However, forest health indicators will be more difficult to assess when monitoring scales are switched from trees to whole forests or biomes (Mildrexler et al., 2009). In forestry, for example, standard forest conditions are measured by productivity. Although wood production is a good representation of productivity, it ignores several important attributes of forest ecosystems, such as species composition, vegetation structure, biomass and nutrient cycling (Costanza et al., 1992; Kolb et al., 1994). This shortcoming needs to be comprehensively revised, but often not so easily defined and quantified. For decades, researchers have been working on the definition of this "healthy" term in ecosystems.

The Food and Agriculture Organization of the United Nations (FAO), based on existing abiotic factors such as dryness, heat and pollution, and biology, such as pests and diseases, combines these perspectives to definite "forest health and vitality"; wood yield and quality, as well as non-timber forest products; wildlife habitats (FAO, 2010; FAO, 2015); and recreational, scenic, or cultural values that affect tree growth and survival.

Edmonds et al. (2000) list eight conditions for a healthy forest: (1) an ecological system in which biological and abiotic factors do not threaten current and future management objectives; (2) the system is a plant, animal, and a full-functional community of their physical environments; (3) it is a balanced ecosystem; (4) the system 
maintains complexity while also provides human needs; (5) the system can adapt to a variety of changes; (6) the system can be recovered from natural and man-made influences; (7) the system maintains all needed functions and procedures; (8) these functions and procedures are free of negative symptoms, such as reduced primary productivity, loss of nutrient capital, loss of biodiversity, widespread occurrence of diseases or potential tree pests and diseases, and so on.

However, if the spatial and temporal scales of forest ecosystems are not taken into account, even a detailed set of attributes still cannot fully capture the definition of forest health. Basically, forests contain trees under cyclic stress (such as drought stress) (Brando et al., 2014; Hartmann et al., 2015), which in addition to affecting strain capacity, and if the stress is intense or recurrent, it will cause death. Here, we differentiate stress from disturbances that can also kill healthy and unhealthy trees (e.g., wind blowing trees down, fire, logging, etc.). Both can produce a dying forest, which may be considered unhealthy in itself, but can also be considered as a set of measures to promote basic ecological processes such as regeneration, nutrient cycling, or habitat creation, with a broader spatial dimension. Thus, a healthy forest is a complex that includes all stages of succession that represent the natural range of disturbance and restoration. These forests promote dynamic nutrient diversity, cover types, and stand structures, while they create a range of endemic animal habitats (Koven et al., 2013). The challenges faced by us are to determine when will happen, pressure and disturbance frequencies, spatial ranges, and intensities that exceed the range of natural variability, which in turn affect the vegetation restoration trajectory from landscape to regional scale.

The time scales of forest function restoration after major disturbances are different. The so-called major disturbances are such as deforestation and fire, followed by soil erosion and forest regeneration (Flannigan et al., 2009). Functions related to leaf area, such as photosynthesis and transpiration, recover in about ten years, while biomass (and thus carbon storage) recovers more slowly, and the slowest recovery is the mineral nutrient (Goetz et al., 2005).

After major disturbances, forest-related functions resume at different time scales. For example, even in severely damaged forests, new foliage can grow in just a few months. Key forest functions such as photosynthesis, transpiration, climate, and water regulation are also restored as leaf area recovers. Depending on the recovery of a number of tropical forests from a fire, these functions may take years to decades to revert to pre-disturbance levels (2010; Lewis et al., 2015). However, many other functions of the forest take longer to recover, for example, forest biomass and functional recovery of carbon storage may take decades to several hundred years to make up for losses.

Other forest functions, such as biodiversity, may take longer to recover, as they depend on the existence of individual species. Although differences exist in forest formation, forest biodiversity can be maintained at landscape or regional levels, but if interventions are too great, such as deforestation and fires, forest biodiversity will be significantly reduced. In this case, the restoration of biodiversity requires tree species to be replaced in all aspects as well as the replacement of the fauna on which they depend. For example, dead wood is an important carbon stockpile and provides a specific faunal habitat; if withered wood is destroyed by logging or burning, it may take several hundred years to recover. Soil-derived nutrients are slowly replenished by atmospheric dust or mineral weathering. Thus, nutrient depletion associated with the disturbance may ultimately limit the rate and extent of recovery of other functions.

At present, the only global systematic forest health assessment is FAO's Global Forest Resources Assessment (FRA), which is based on a variety of forest-affected countries affected by various factors such as fire, pests, diseases, physical destruction of animals, extreme weather and species invasions area, assessing the forest health and vitality in various countries or regions (Kayler et al., 2015). FAO assessments represent the use of the ecosystem approach and are therefore less affected by stakeholders, and are not, in fact, a practical assessment that relies on the provision of national forest information, together with information obtained from remote sensing technologies, such as global forest distribution and land-use change.

Forests exist much longer than human history, and survive many climate changes. In the long term, forests may be sufficient to withstand the rapidly changing climate and environment of mankind, both in the present form and in the future composition of the community. Human concerns about forest health are mainly reflected in our continued availability and dependency on the products and functions provided by forests, making it necessary for us to monitor and evaluate forest conditions and health on a continuous basis.

\section{Conclusions and Perspectives}

Humans have domesticated our soil resources in this planet for millions of years (Steffen et al., 2015). However, the domestication has in turn perturbed a number of soil cycles, such that they are no longer in balance, and the 
imbalance is changing the soil in ways that will affect future generations and global climate. Soil management must be geared toward passing a habitable and albeit highly altered landscape to the generations that follow from one to another where our exploitation of (Alencar et al., 2015), and impacts on, soil resources is adjusted to the pace of our planet's renewal, focusing on a balance in (1) organic C inputs and losses; (2) soil erosion and production; and (3) release and loss of nutrients.

In the 21 st century, there are challenging goals that will be difficult to achieve. The solutions will require an effort commensurate with the magnitude of the problems. First of all, we need effective solutions for the soil sustainability, much like the approaches required to contend with climate change, involve highly multidisciplinary research in novel intellectual settings or institutions. Second, the ultimate success of any innovation requires a dialog and interface with policymakers and public institutions, which are the ultimate "deciders" in broad-scale social change.

In terms of forest health, the FAO assessment now provides the best-available information on the areas of forest subjected to different kinds of disturbances. Another initiative that would benefit from better quantification of changes in forest conditions is the United Nations program for Reducing Emissions from Deforestation and forest Degradation, which is an economic instrument for rewarding tropical nations that avoid carbon emissions to the atmosphere or regain carbon by reforestation (Hansen et al., 2010). Given the global importance of forests, the projections of increased future disturbances, and the needs to inform conservation mechanisms, it is vital to design an approach capable of identifying the transition from healthy to unhealthy forests as well as characterize the underlying causes. These include the development of a strong enough understanding of the background levels of forest disturbance in order to identify events that could alter recovery trajectories.

Forests have existed for far longer than humans and have already survived a wide range of past changes in climate conditions. Over the long term, forests will probably prove resilient to rapid anthropogenic changes in climate and environment, whether in their current form or in novel community assemblages.

\section{References}

Alencar, A. A. C., Brando, P. M., Asner, G. P., \& Putz, F. E. (2015). Landscape fragmentation, severe drought and the new Amazon forest fire regime. Ecol. Appl. 25, 1493-505. https://doi.org/10.1890/14-1528.1

Amundson, R. (2001). The carbon budget in soils. Annu. Rev. Earth Planet. Sci. 29, 535-562. https://doi.org/10.1146/annurev.earth.29.1.535

Amundson, R., Berhe, A. A., Hopmans, J. W., Olson, C., Sztein, A. E., \& Sparks, D. L. (2015). Soil and human security in the 21st century. Science, 348(6235). https://doi.org/10.1126/science.1261071

Amundson, R., Guo, Y., \& Gong, P. (2003). Soil diversity and land use in the United States. Ecosystems 6, 470482. https://doi.org/10.1007/s10021-002-0160-2

Asner, G. P., Keller, M., \& Silva, J. N. M. (2004). Spatial and temporal dynamics of forest canopy gaps following selective logging in the eastern Amazon. Glob. Change Biol. 10, 765-783. https://doi.org/10.1111/j.1529-8817.2003.00756.x

Bardgett, R. D., \& van der Putten, W. H. (2014). Belowground biodiversity and ecosystem functioning. Nature 515, 505-511. https://doi.org/10.1038/nature13855

Brando, P. M. et al. (2014). Abrupt increases in Amazonian tree mortality due to drought-fire interactions. Proc. Natl. Acad. Sci. U.S.A. 111, 6347-6352. https://doi.org/10.1073/pnas.1305499111

Burke, E. J., Hartley, I. P., \& Jones, C. D. (2012). Uncertainties in global temperature change caused by carbon release from permafrost thawing. The Cryosphere, 6, 1063-76. https://doi.org/10.5194/tc-6-1063-2012

Cao, L., Bala, G., Caldeira, K., Nemani, R., \& Ban-Weiss, G. (2010). Importance of carbon dioxide physiological forcing to future climate change. Proc. Natl. Acad. Sci. U.S.A. 107, 9513-9518. https://doi.org/10.1073/pnas.0913000107

Cordell, D., Drangert, J.-O., \& White, W. (2009). The story of phosphorus: Global food security and food for thought. Glob. Environ. Change19, 292-305. https://doi.org/10.1016/j.gloenvcha.2008.10.009

Costanza, R., Norton, B., \& Haskell, B. (1992). in Ecosystem Health: New Goals for Environmental Management. In R. Costanza (Ed.), (pp. 239-256). Island Press, Washington, DC.

Diamond, J. (2002). Evolution, consequences and future of plant and animal domestication. Nature 418, 700 707. https://doi.org/10.1038/nature01019

Doetterl, S., Van Oost, K., \& Six, J. (2012). Towards constraining the magnitude of global agricultural sediment 
and soil organic carbon fluxes. Earth Surf. Process. Landf., 37, 642-655. https://doi.org/10.1002/esp.3198

Edmonds, R. L., Agee, J. K., \& Gara, R. I. (2000). Forest Health and Protection. McGraw-Hill, New York.

Ehrlich, P. R., \& Wilson, E. (1991). Biodiversity studies: Science and policy. Science, 253, 758-762. https://doi.org/10.1126/science.253.5021.758

Elser, J., \& Bennett, E. (2011). Phosphorus cycle: A broken biogeochemical cycle. Nature, 478, 29-31. doi: 10.1038/478029a; pmid: 21979027

FAO. (2010). Global Forest Resources Assessment 2010 (FAO Forestry Paper 163, FAO, Rome).

FAO. (2011). FAO in the 21st Century: Ensuring Food Security in a Changing World (Food and Agriculture Organization of the United Nations, Rome).

FAO. (2015). Global Forest Resources Assessment 2005, FAO Forestry Paper 147, FAO, Rome.

Flannigan, M., Stocks, B., Turetsky, M., \& Wotton, M. (2009). Impacts of climate change on fire activity and fire management in the circumboreal forest Glob. Change Biol., 15, 549-560. https://doi.org/10.1111/j.1365-2486.2008.01660.x

Gauthier, S., Bernier, P., Kuuluvainen, T., Shvidenko, A. Z., \& Schepaschenko, A. D. (2015). Boreal forest health and global change. Science, 349, 819-822. https://doi.org/10.1126/science.aaa9092

Gedney, N. et al. (2006). Detection of a direct carbon dioxide effect in continental river runoff records. Nature, 439, 835-838. https://doi.org/10.1038/nature04504

Goetz, S. J., Bunn, A. G., Fiske, G. J., \& Houghton, R. A. (2005). Satellite-observed photosynthetic trends across boreal North America associated with climate and fire disturbance. Proc. Natl. Acad. Sci. U.S.A., 102, 13521-13525. https://doi.org/10.1073/pnas.0506179102

Guo, L. B., \& Gifford, R. M. (2002). Soil carbon stocks and land use change: A meta analysis. Glob. Change Biol., 8, 345-360. https://doi.org/10.1046/j.1354-1013.2002.00486.x

Guo, Y., Gong, P., \& Amundson, R. (2003). Pedodiversity in the United States. Geoderma, 117, 99-115. https://doi.org/10.1016/S0016-7061(03)00137-X

Hansen, M. C., Stehman, S. V., \& Potapov, P. V. (2010). Reply to Wernick et al.: Global scale quantification of forest change. Proc. Natl. Acad. Sci. U.S.A., 107, 8650-8655. https://doi.org/10.1073/pnas.0912668107

Hartmann, H., Adams, H. D., Anderegg, W. R. L., Jansen, S., \& Zeppel, M. J. B. (2015). Research frontiers in drought - induced tree mortality: crossing scales and disciplines. New Phytol., 205, 965-969. https://doi.org/10.1111/nph.13246

Jackson, R. B., \& Schlesinger, W. H. (2004). Curbing the U.S. carbon deficit. Proc. Natl. Acad. Sci. U.S.A., 101, 15827-15829. https://doi.org/10.1073/pnas.0403631101

Janisch, J. E., \& Harmon, M. E. (2002). Successional changes in live and dead wood carbon stores: implications for net ecosystem productivity. Tree Physiol., 22, 77-89. https://doi.org/10.1093/treephys/22.2-3.77

Jobbágy, E. G., \& Jackson, R. B. (2000). The vertical distribution of soil organic carbon and its relation to $\begin{array}{lllll}\text { climate } \quad \text { and } & \text { Ecolation. }\end{array}$ https://doi.org/10.1890/1051-0761(2000)010[0423:TVDOSO]2.0.CO;2

Jones, D. L., et al. (2013). Nutrient stripping: The global disparity between food security and soil nutrient stocks. J. Appl. Ecol., 50, 851-862. https://doi.org/10.1111/1365-2664.12089

Kayler, Z. E., De Boeck, H. J., Fatichi, S., Grünzweig, J. M., Merbold, L., Beier, C. ... Dukes, J. S. (2015). Experiments to confront the environmental extremes of climate change, Front. Ecol. Env, 13, 219-225. https://doi.org/10.1890/140174

Kirkby, M. J. (1967). Measurement and theory of soil creep. J. Geol., 75, 359-378. https://doi.org/10.1086/627267

Koch, A. et al. (2013). Soil security: Solving the global soil crisis. Glob. Policy, 4, 434-441. https://doi.org/10.1111/1758-5899.12096

Kolb, T. E., Wagner, M. R., \& Covington, W. W. (1994). Concepts of ecosystem health: utilitarian and ecosystem perspectives. J. For, 92, 10-15.

Koven, C. D., et al. (2013). The effect of vertically resolved soil biogeochemistry and alternate soil C and N models on C dynamics of CLM4. Biogeosciences, 10, 7109-7131. https://doi.org/10.5194/bg-10-7109-2013 
Lal, R. et al. (2008). Soil erosion: A carbon sink or source? Science, 319, 1040-1042. https://doi.org/10.1126/science.319.5866.1040

Levick, S. R., \& Asner, G. P. (2013). The rate and spatial pattern of treefall in a savanna landscape Biol. Conserv. 157, 121-127. https://doi.org/10.1016/j.biocon.2012.07.009

Lewis, S. L., Edwards, D. P., \& Galbraith, D. (2015). Increasing human dominance of tropical forests. Science, 349, 827-832. https://doi.org/10.1126/science.aaa9932

Lieth, H. (1973). Primary production: Terrestrial ecosystems. Hum. Ecol., 1, 303-332. https://doi.org/10.1007/BF01536729

Litchman, E., Edwards, K. F., \& Klausmeier, C. A. (2015). Microbial resource utilization traits and trade-offs: implications for community structure, functioning, and biogeochemical impacts at present and in the future. Front. Microbiol., 6, 254. https://doi.org/10.3389/fmicb.2015.00254

Marengo, J. A., Tomasella, J., Soares, W. R., Alves, L. M., \& Nobre, C. A. (2012). Extreme climatic events in the Amazon basin Climatological and hydrological context of recent floods. Theor. Appl. Climatol., 107, 73-85. https://doi.org/10.1007/s00704-011-0465-1

Mildrexler, D. J., Zhao, M., \& Running, S, W. (2009). Testing a MODIS global disturbance index across North America, Remote Sens. Environ., 113, 2103-2117. https://doi.org/10.1016/j.rse.2009.05.016

Mildrexler, D. J., Zhao, M., Heinsch, F. A., \& Running, S. W. (2007). A new satellite-based methodology for continental-scale disturbance detection. Ecol. Appl., 17, 235-250. https://doi.org/10.1890/1051-0761(2007)017[0235:ANSMFC]2.0.CO;2

Millar, C. I., \& Stephenson, N. L. (2015). Temperate forest health in an era of emerging mega disturbance. Science, 349, 823-826. https://doi.org/10.1126/science.aaa9933

Montgomery, D. R. (2007). Soil erosion and agricultural sustainability. Proc. Natl. Acad. Sci. U.S.A., 104, 13268-13272. https://doi.org/10.1073/pnas.0611508104

Post, W. M., Emanuel, W. R., Zinke, P. J., \& Stangenberger, A. G. (1982). Soil carbon pools and world life zones. Nature, 298, 156-159. https://doi.org/10.1038/298156a0

Quinton, J. N., Govers, G., Van Oost, K., \& Bardgett, R. (2010). The impact of agricultural erosion on biogeochemical cycling. Nat. Geosci., 3, 311-314. https://doi.org/10.1038/ngeo838

Ruddiman, W. F. (2007). The early anthropogenic hypothesis: Challenges and responses. Rev. Geophys., 45, RG4001. https://doi.org/10.1029/2006rg000207

Ruddiman, W. F. (2013). The Anthropocene. Annu. Rev. Earth Planet. Sci., 41, 45-68. https://doi.org/10.1146/annurev-earth-050212-123944

Smil, V. (2011). Nitrogen cycle and world food production. World Agriculture, 2, 9-13.

Smith, P. (2005). An overview of the permanence of soil organic carbon stocks: Influence of direct human-induced, indirect and natural effects. Eur. J. Soil Sci., 56, 673-680. https://doi.org/10.1111/j.1365-2389.2005.00708.x

Smith, P. et al. (2007). "Agriculture," in Climate Change 2007: Mitigation. Contribution of Working Group III to the Fourth Assessment Report on the International Panel of Climate Change. Cambridge Univ. Press, Cambridge.

Smith, P. et al. (2008). Greenhouse gas mitigation in agriculture. Philos. Trans. R. Soc. London Ser. B 363, 789-813. https://doi.org/10.1098/rstb.2007.2184

Sposito, G. et al. (1999). Surface geochemistry of the clay minerals. Proc. Natl. Acad. Sci. U.S.A., 96, 33583364. https://doi.org/10.1073/pnas.96.7.3358

Stallard, R. F. (1998). Terrestrial sedimentation and the carbon cycle: Coupling weathering and erosion to carbon burial. Global Biogeochem Cycles, 12, 231-257. https://doi.org/10.1029/98GB00741

Steffen, W. et al. (2015). Planetary boundaries: Guiding human development on a changing planet. Science, 347, 1259855-1259855. https://doi.org/10.1126/science.1259855

Stockmann, U. et al. (2013). The knowns, known unknowns and unknowns of sequestration of soil organic carbon. Agric. Ecosyst. Environ., 164, 80-99. https://doi.org/10.1016/j.agee.2012.10.001 
Sun, W., Shao, Q., Liu, J., \& Zhai, J. (2014). Assessing the effects of land use and topography on soil erosion in the Loess Plateau in China. Catena, 121, 151-163. https://doi.org/10.1016/j.catena.2014.05.009

Sundquist, E. T. (1993). The global carbon dioxide budget. Science, 259, 934-941. https://doi.org/10.1126/science.259.5097.934

Tennesen, M. (2014). Rare earth. Science, 346, 692-695. https://doi.org/10.1126/science.346.6210.692

Todd-Brown, K. E. O. et al. (2013). Causes of variation in soil carbon simulations from CMIP5 Earth system models and comparison with observations. Biogeosciences, 10, 1717-1736. https://doi.org/10.5194/bg-10-1717-2013

Todd-Brown, K. E. O. et al. (2014). Changes in soil organic carbon storage predicted by Earth system models during the 21st century. Biogeosciences, 11, 2341-56. https://doi.org/10.5194/bg-11-2341-2014

Wall, D. H., Bardgett, R. D., \& Kelly, E. (2010). Biodiversity in the dark. Nat. Geosci., 3, 297-298. https://doi.org/10.1038/ngeo860

Wilkinson, B. H., \& McElroy, B. J. (2007). The impact of humans on continental erosion and sedimentation. Geol. Soc. Am. Bull., 119, 140-156. https://doi.org/10.1130/B25899.1

Wingfield, M. J., Brockerhoff, E. G., Wingfield, B. D., \& Slippers, B. (2015). Planted forest health: The need for a global strategy. Science, 349, 832-836. https://doi.org/10.1126/science.aac6674

\section{Copyrights}

Copyright for this article is retained by the author(s), with first publication rights granted to the journal.

This is an open-access article distributed under the terms and conditions of the Creative Commons Attribution license (http://creativecommons.org/licenses/by/4.0/). 